\title{
PRINCIPLES OF ECONOMIC IBN TAYMIYYAH (Moral Analysis)
}

\author{
Duriana \\ IAIN Imam Rijali Ambon \\ (hj_duriana@yahoo.co.id)
}

\begin{abstract}
This paper discusses the economic principles of Ibn Taymiyyah with moral analysis. The purpose of this paper is to reveal the position of morality in economic principles of Ibn Taymiyyah. There are two issues to be answered in this paper are: how is the economic principles of Ibn Taymiyyah, and how is the moral position in the economic principles of Ibn Taymiyyah. This research was found: principles of Ibn Taymiyyah's economy include: the principle of balance, fairness, sharia, cooperation, consultation and the prohibition of usury. Moral position in the economic principles of Ibn Taymiyyah is the basis and foundation of the economy which is essentially based on justice as a moral parent intended to protect the public from a variety of exploitative actions.

Tulisan ini membahas tentang prinsip-prinsip ekonomi Ibnu Taimiyah dengan analisis moral. Tujuannya adalah untuk mengungkap posisi moralitas dalam prinsip-prinsip ekonomi Ibnu Taimiyah. Terdapat dua masalah yang ingin dijawab dalam tulisan ini yaitu: 1. Bagaimana prinsip-prinsip ekonomi Ibnu Taimiyah? 2. Bagaimana posisi moral dalam prinsip-prinsip ekonomi Ibnu Taimiyah? Berdasarkan penelusuran yang dilakukan ditemukan bahwa: Prinsip-prinsip ekonomi Ibnu Taimiyah meliputi: Prinsip keseimbangan, keadilan, syariah, kerja sama, musyawarah dan larangan riba. Posisi moral dalam prinsip ekonomi Ibnu Taimiyah menjadi dasar dan pondasi ekonomi yang pada hakekatnya bertumpu pada penegakan keadilan sebagai induk moral yang bertujuan melindungi masyarakat dari berbagai tindakan eksploitatif.
\end{abstract}

Keywords: Ibn Taymiyyah; principles; justice; morality 


\section{A. Introduction}

The fundamental economic problems facing mankind in the history of economic development is the emergence of a view that puts the aspect of material that is free of the dimensions of spiritual and moral values. View of life which is based on the ideology of materialism is then pushed human behavior into economic actors hedonist, secularists and materialist. ${ }^{1}$ As a result, there arises the chaos and economic instability could even lead to economic recession.

Human life can not be separated from economic problems which involve human relationships with other human beings, as people who believe and declare Islam as a religious choice that relationship must be based on moral values/morals of Islam which became one of the main values in the order of human life including those relating to economic issues, so that economic life can work well and can provide prosperity for all people of the world and the hereafter.

Moral/morals is one of the main pillars of people's lives throughout history, both as individuals and as members of society and the nation. History has proved that a nation becomes solid when supported by a moral society/morality, and instead of a nation will collapse when the moral/morals corrupted society. Arab poet Syauqi Bey in his famous poem says:

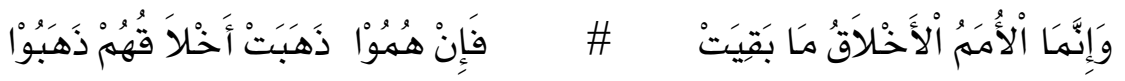

"An eternal nation as moral (character favor). When the mind in attitude has collapsed then collapsed precisely that nation."”2

The quote shows how significant the character is good for man in the life of the nation, including in running the economy. Because it's good or bad the economy of a nation is determined by the good and bad morals economic actors.

Islam is the only religion that regulates all aspects of perfect human life and the universe. Human economic activity is also regulated in Islam with the principles illahiyah. Property owned by humans, is not really belong in the absolute, but only the grace of Allah. in order to be best utilized for the sake of benefit for mankind which will be accountable before Allah.

${ }^{1}$ Imamuddin Yuliadi, Ekonomi Islam, Filosofi, Teori dan Implemtasi, edisi revisi, (Yogyakarta: University of Muhammadiyah, 2007), p. 1.

${ }^{2}$ Syauqi Bey dalam Hamzah Ya'qub, Etika Islam; Pembinaan Akhlaqul Karimah, (4 ${ }^{\text {th }}$ edition: Bandung: Dipenogoro, 1993), p. 30. Can olso be seen in Sahilun A. Nasir, Tinjauan Akhlak (First Edition: Surabaya: al-Ikhlas, 1990), p. 12. 
This paper attempts to look at the position of moral/morals in economic principles of Ibn Taymiyyah by asking two fundamental questions, namely: how economic principles Ibn Taymiyyah? and how to position moral/morals in economic principles Ibn Taymiyyah?.

It is worth to be reexamined because according Karnaen A. Poerwataatmadja, economic thought Ibn Taymiyyah very rich, sharp, and wide for the development of economic science. Besides the discussion-rich discussion with moral messages/morals so that economic thinking is not obsolete and outdated even can be used as a major foothold in the developing economies of dignity.

This study is a literature research using qualitative methods. This method is used to uncover relevant literature is more emphasis on the meaningfulness of refined philosophically, theoretically, and related cultural value system.

\section{B. Curriculum Vitae of Ibn Taymiyyah}

1. Birth

Curriculum vitae including a thinker and intellectual development objective reality that surrounds her life are things that need to be considered in order to understand his thinking objectively.

In parallel with the fall of Baghdad in the year $656 \mathrm{H} / 1257 \mathrm{M}$, right on Monday, 12 Rabiul Awwal 661 H./1263 M. Ibn Taymiyyah was born in a town that lies between the rivers Euphrates Dajlah and called Harran, a town which is included in Khorasan region (Persian). His parents gave the name Ahmad. And historians write his full name to: Taqi al-D n Ab al-'Abb s Ahmad Ibn 'Abd alHalim Ibn 'Abd al-Sal m Ibn Abi al-Q sim Ibn Muhammad Ibn Taymiyyah alHarrani al-Dimasyq . ${ }^{3}$ His parents took him to Damascus when he was 7 years because of Khurasan Tartar Mongols attacked by troops under the command of Hulagu Khan (1256-1265M). ${ }^{4}$

${ }^{3}$ Ibnu Kaṡ r, Al-Bidāyah wa al-Nihāyah, Jilid 13 (Ed. 1; Beirut Maktabah alMa’ rif, 1966), p. 308. See also al-Zahab, Tazkirat al-Huffāz, Volume 4 (Haidar Abad: t.th.), p. 288.

${ }^{4}$ Power Mongol period is a time of very severe split in the cultural history of Islam, there is a huge empire on which the hopes of Muslims and many large libraries were destroyed along with their books. Seen Musyrifah Sunanto, Sejarah Islam Klasik Perkembangan Ilmu Pengetahuan Islam (Ed.1; Bogor: Kencana, 2003), p. 194-195. Seen also Yusran Asmuni, Pengantar Studi Pemikiran dan Gerakan Pembaruan dalam Islam (Ed. 2; Jakarta: Raja Grafindo Persada, 1998), p. 52. 
Ibn Taymiyyah came from Islamic intellectual family, a family that valued and respected the public at large at the time. His father was Syih budd $\mathrm{n}$ $\mathrm{Ab}$ al-Mah sin 'Abd al-Hal m ibn Taymiyyah (d. $1284 \mathrm{M}$ ). ${ }^{5}$

Mom Ibn Taymiyyah had seen the glory of his son, even took part in their jihad. When her son was imprisoned by King al-Nasir, his mother came to him and begged his son released from prison, his request was granted by the king and eventually Ibn Taymiyyah was released. But then imprisoned again.

2. Education

Ibn Taymiyyah received his early education from his father and from his uncle al-Khatib Fakhruddin, a thinker and writer famous. He also studied at the scholars in Damascus who at that time became one of the centers of science and culture and is a gathering place for great scholars of the various schools. ${ }^{6} \mathrm{Ibn}$ Taymiyyah knowledge is not limited to studies of the Qur'an, hadith and fiqh alone, but also to learn and experts in the field of matematika, history, literature and specifically explore the Hanbali fiqh because his father was a man of this school. $^{7}$

Islamic world in the era of Ibn Taymiyyah before and after birth is a turbulent Islamic world. The turmoil of thought and also prolonged political turmoil. Ibn Taymiyyah himself was born exactly five years after Baghdad fell and the capital of Islam ravaged nation in the hands of the Tartars. ${ }^{8}$

There are several other factors in addition it can also be concluded as the cause of the brilliance of thought of Ibn Taymiyyah in the future. Among them are as follows:

a. Memorizing and understanding the power of incredible. At the very young age he managed to finish memorizing al-Quran.

b. Personal readiness to continue researching. He never tired of studying and researching, even when he should be in jail.

${ }^{5}$ Sa'id 'Abdul 'Az m, Ibn Taimiyah; al-Tajd d al-Salaf wa al-Da'wah alIșl hiyyah. Translated by Faisal Saleh and Khoirul Amru Harahap: Ibn Taimiyah, Pembaruan Salafi dan Dakwah Reformasi (Ed. 1; Jakarta: Pustaka al-Kautsar, 2005), p. 15.

${ }^{6}$ Masyharuddin, Pemberontakan Tasawuf, Kritik Ibnu Taimiyah Atas Rancang Bangun Tasawuf (Ed.1; Kudus: JP Books, 2007), p. 29.

${ }^{7}$ Abu Muhammad Ibnu Sa’ d Ibnu Rusl n, Hawla Hayātu Syaikh al-Islām Ibnu Taimiyah Rahimahullāh, ( ${ }^{\text {nd }}$ editions; Maktabat al-Man r, 2002), p. 53.

${ }^{8}$ Sa' d 'Abdul 'Az m, op. cit., p. 13-15. See also Ibnu Hajar al-'Aśqal n, alDurār al-Kāmilah fì A'yān al-Mi'ah al-Śaminah, Volume 1 (D r al-Ma' rif, 1947), p. 144. 
c. Independence of mind which is not tied to any particular school of thought or sight. Her proposition is its handle in proposition. Therefore he also called for the opening of the doors of ijtihad. ${ }^{9}$

Ibn Taymiyyah's life journey was not smooth. Due to the principles he advocated, he must accept the risk several times in and out of prison. At least eight times through the days in prison. He died on the evening of Monday 20 Zulqaidah $728 \mathrm{H}^{10}$

3. His Creation

Ibn Taymiyyah left around 500 volumes creation in a variety of disciplines. Most can be read up to now. Ibn al-Wardy $($ d. $749 \mathrm{H})$ states that in a day and night, Ibn Taymiyyah may write four books.

Ibn Taymiyyah's writings cover a wide range of scientific fields such as interpretation, tafsir, hadith, the science of hadith, fiqh, usul fiqh, morals, sufism, mantiq (logic), philosophy, politics, tawhid (kalam), economic and others. Most of his creation has been collected in Majmoo 'al-Fatāwa which amounted to 37 volumes, not including some of his works were categorized as large as Minhaj al-Sunnah and others.

Ibn Taymiyyah economic rationale contained in his landmark creation that is Majmoo 'al-fatāwa, al-Siyasah al-Syar'iyah fi ishlāh al-Rā'i wa alRa'iyah and al-Hisbah fi al-Islām.

\section{Economics Principles of Ibn Taymiyyah \\ 1. The balance of the price}

Ibn Taymiyyah concept of equilibrium price can be seen from the description when talking about the equivalent price. For Ibn Taymiyyah equivalent price is the price established by market forces running freely, the meeting between the power demand by bidding. This is what is meant by the price balance in the 13th century AD were delivered by ST. Thomas. And Ibn Taymiyyah had preceded discovered in the 11 th century AD equivalent price can also be interpreted as a standard price prevailing when the people selling wares and is generally accepted as an equivalent for such goods or similar goods in specific time and place.

${ }^{9}$ Ibnu Taimiyah, Minḥajj al-Sunnah al-Nabawiyyah, Taḥ q: Muhammad Rasyad S lim, Jilid 2 (Maktabah al-Riy d al-Had sah, t.th.), p. 288. See also Abd alFattah Muhammad Sayyid Ahmad, al-Tașawwuf Baina al-Ghazalī wa Ibnu Taimiyah, (First edition; al-Q hirah: D r al-Waf , 2000 M), p. 189-190.

${ }^{10}$ Muhammad Ibnu Sa' d Ibnu Rusl n, op. cit., p. 49. See also Ibr h m Zak Hurșid, Da'irat al-Ma 'ārif al-Islāmiyah (Not a Pub.: Maṭba'ah al-Sya'b, 1969), p. 235 . 
Islam teaches balance in a variety of activities and dimensions of life, because Islam as a doctrine that brings treatise contains a moral message for the creation order of life that bring goodness and prosperity for all beings of the universe (rahmatan lil 'âlamin). The concept of equilibrium in the Qur'an have been described in the Q.S al-Qashas/28:77.

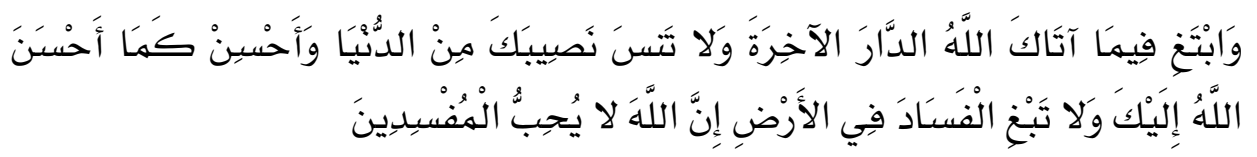

"But seek, through that which Allah has given you, the home of the Hereafter; and [yet], do not forget your share of the world. And do good as Allah has done good to you. And desire not corruption in the land. Indeed, Allah does not like corrupters. ${ }^{11}$

According to Ibn Taymiyyah market in terms of economics is the meeting between demand and supply. In this sense, the market is interactive, not physical. The market mechanism is the process of determining the level of prices is based on the strength of demand and supply. The meeting between demand (demand) and supply (supply) is called the equilibrium price (price balance). ${ }^{12}$

Ibn Taymiyyah's ideas about emerging market balance of the public perception of his day that high price in the market is a result of injustice and lawlessness that dilakukakn by the seller. Ibn Taymiyyah has denied this and said that the prices are determined by forces of supply and demand. Rise and fall of prices is not always caused by injustice. Price increase could be due to decreased supply due to production inefficiencies, reduction in the amount of imports, and market pressures. ${ }^{13}$ Furthermore, he said that if all transactions are in accordance rule but prices remain high, then as religious people should return to the provisions of Allah. ${ }^{14}$

Ibn Taymiyyah also said that the price is also affected by the level of confidence in the persons involved in the transaction. When someone propesional and trustworthy or reliable in paying the credit, then the seller will

${ }^{11}$ Ministry of Religion RI, Alquran andg his Translation (Jakarta: Pustaka Maghfirah, 2006), p. 393.

12 Euis Amalia, Sejarah Pemikiran Ekonomi Islam, (Ed.1; Jakarta: Pustaka Asatruss, 2005), p. 163-164.

${ }^{13}$ Karnaen et.all., in Adiwarman Azwar Karim, Pasar yang Sehat Menurut Ibnu Taimiyah (Jakarta: Rajawali Press, 2001), p. 330.

${ }^{14}$ Karnaen at'all., in Ibnu Taimiyah, Majmû' Fatāwa, Volume 8, p. 583. 
believe it and feel happy to transact with the person. However, if the credibility of the credit problems have doubt then the seller will be reluctant to transact with the person even if he did he put up transaction prices high. ${ }^{15}$

Ibn Taymiyyah has a clear vision of how in a free market, the price considered by the forces of supply and demand:

Rise and fall of prices is not always associated with injustice (zhulm) done by someone. Occasional reason is the shortage in production or a decrease in imports of goods requested. If it requires an increase in the amount of goods while ability decreases, prices will naturally rise. On the other hand, if the ability of the supply of goods increases and demand decreases, then the price will go down.

The statement indicates that there is a habit that occurred at the time of Ibn Taymiyyah that the price increase is due to injustice or tyranny of the sellers, so that the word used is zulm, which means lawlessness or injustice. ${ }^{17}$ He said, prices could rise due to the decrease number of available goods or an increase in the number of residents. Decrease in other words goods are jatuhya supply. While the increase in population will lead to an increase in demand, because it can be regarded as "increased demand". The rise in prices since the fall of supply, in case it is characterized as God, indicates that the market mechanism is a natural condition that is impersonal.

Ibn Taymiyyah recommend pricing by the government and force the sale of the materials when the basic needs in emergency situations, such as famine. At the moment it is time the authorities can force someone to sell the goods on actual prices because of the population's need.

According to Ibn Taymiyyah, may offer come from domestic production and imports. Changes in supply described as an increase or decrease in the number of goods on offer, while demand is largely determined by the tastes and incomes. The size of the price increase depends on the size and or request changes captors.

${ }^{15}$ Ibid., p. 523-525.

${ }^{16}$ Ali Warman Azwar Karim, Ekonomi Islam; Suatu Kajian Kontemporer, (Jakarta: Gema Insani Press, 2001), p.160.

${ }^{17}$ Muhammad Abdul Manan, Teori dan Praktek Ekonomi Islam, (Yogyakarta: Dana Bhakti Wakaf, 1998), p. 34. See also D. Imamudin Yuliadi, Ekonomi Islam, Filosofi, Teori, dan Implemtasi (Yogyakarta: Study and Practice of Islamic Institutions: Muhammadiyah University, 2007), p. 59-60. 


\section{Justice}

a. Fair price

The principle of a fair price, is the biggest contribution of the economic thought of Ibn Taymiyyah. There are two important themes in the discussion of the issue at a fair price.

First, equal or fair compensation ('iwad al-Mysl) and price equal or fair (tam $\mathrm{m}$ al-mysl). Equivalent compensation to be measured and assessed by similar things and that is the essence of justice (nafs $a l$-' $a d l$ ). Fair compensation is commensurate replacement which is a price equal to the value of an object according to custom. Equivalent compensation is measured and assessed by similar things without any addition and subtraction, this is where the essence of justice.

Second, the price of an equivalent as a fair price. So two words, fair "and equitable. In defining compensation equivalent, he said, is meant by equality is the quantity of a particular object in general use is associated with a base value (rate/si'r) and custom (al-'adah), he added: evaluation of the right to compensation fair and estimates based on the analogy of the goods with other goods equivalent (equivalent). ${ }^{18}$

The concept of a fair price essentially existing and used by the jurists since the beginning of the Islamic presence. Koran it self is very stressed justice in every aspect of human life. Therefore, it is reasonable if justice is also manifested in market activity, in particular the price.

The concept of Ibn Taymiyyah regarding compensation equivalent ('iwâdh al-mysl) are not the same as the fair price (tamam al-mysl). Fair compensation according to Ibn Taymiyyah is the replacement of which is a price well worth the equivalent of an object according to the custom prevailing in society. Furthermore, compensation is equal objects or goods are to be assessed by similar things without any addition and subtraction. This is where the truth is justice according to Ibn Taymiyyah. ${ }^{19}$ The question of fair compensation or equivalent ('iwâdh al-mysl) addresses problems arise when the moral and legal obligations with regard to the ownership of the goods. These principles are contained in the following cases:

1) When a person should be responsible for endangering other people, property and profits. 2) When a person has an obligation to repay the amount of goods or equivalent benefits or pay compensation for injuries that afflict the majority of the members of one's body. 3) When a person is asked to determine the contract

${ }^{18}$ Nur Chamid, Jejak Langkah Sejarah Pemikiran Ekonomi Islam (Ed. 1; Yogyakarta: Pustaka Pelajar, 2010), p. 232.

${ }^{19}$ Ibid. 
was broken (al-'ukud al-fasidah) and the contract that is authentic (al-Uqud alshahihah) in an event that deviates in life and property. ${ }^{20}$

Retrospective case series-case is not a case of the exchange rate but as compensation or execution of an obligation.

b. Fair wages

The concept of fair wages according to Ibn Taymiyyah reference to the prevailing price level of the labor market (tas'ir fi al-'amâl) and use the term equal remuneration (ujrah al-mysl). As well as price, the basic principle which is the object of observation in determining wage levels is a thorough definition of quality and quantity. Prices and wages, when not certain, unspecified, and not specified or unknown, is something that is vague and give rise to speculation.

The concept of fair wages intended as wage levels that must be given to the workers so that they can live a decent center of a community. For example before the workers are hired, workers should already know the wages to be received from the provider or employer's work. So there is an element of willingness among workers and labor providers with regard to price levels prevailing in the market.

c. Earnings Fair

Ibn Taymiyyah acknowledges the idea of profit is the motivation traders. According to him, traders are entitled to benefit in ways that are acceptable in general (al-ribh al ma'rûf) does not damage the interests of himself and the interests of others (customers).

Ibn Taymiyyah defines fair profit as a normal profit that is generally derived from a particular type of trade, without harming others. He opposed an unusual advantage, exploitative by utilizing public indifference towards the existing market mechanisms. The main purpose of a fair price and a variety of other related things is to uphold justice in exchange transactions and other relations among members of the public. It is also intended as a guide for the authorities to protect the public from a variety of exploitative actions. In other words, this concept may make it easier for people to reconcile moral obligation with financial liabilities. In the view of Ibn Taymiyyah, fair for traders means the merchandise they are not forced to sell at a price that can eliminate their normal profit.

Justice meaningful balance between the various aspects of life between individu and social aspects, between rights and obligations, between the interests of the world and the hereafter, between the physical and spiritual needs, and so on. Justice concept has been described in Q.S. al-Maidah/5: 8.

\section{Sharia in Property Rights}

Islamic principles of Islamic economics means authentic sources of Islam which includes al-Quran, Sunnah, and ijtihad became a reference in any

${ }^{20} I b i d .$, p. 233. 
economic activity. It is set up to guard against the chaos in all economic activities.

According to Ibn Taymiyyah, it is possible the use of property rights to the extent not contrary to Islamic principles. On the acquisition of individual property rights, is justified as long as the sharia corridor. Such as securing ownership of goods (soil) displaced by the owners obviously do not have to be cultivation, inheritance, sales and so on. Every individual has the right to enjoy his property, use it productively, move and protect from superfluous, however, that right is limited by a number of conditions. He should not be used arbitrarily and prohibited for the purpose luxuries. In economic transactions he must not use illicit means, such as fraud, forgery and stealing scales or sizes.

\section{Cooperation}

In the case of activities related to economic transactions, Ibn Taymiyyah said five (5) forms of cooperation, namely:

a. Cooperation in the capital, two or more people who accumulate capital, and work together and share the results of their profits

b. Cooperation in energy, namely some artisan or worker joins handle a job to divide their earnings among themselves.

c. Cooperation in the credits, which is one or more members of an organization to get their goods on credit and then sell them, and they agreed to split the profits.

d. Comprehensive cooperation (syirkah al-mufawadah), namely cooperation in various forms of capital, labor, and credit.

e. Cooperation mudaraba (syirkah al-mudaraba), one party provides the capital and one party provides the power. In case of a loss on cooperation mudaraba, covered only capital losses on the one hand, the owners of capital, being the party that provides power did not get anything from their work.

In the case of this form of cooperation Ibn Taymiyyah did not explain in detail, such as what if the loss was caused by fraud or negligence of the party providing the power. Ibn Taymiyyah also does not explain how the pillars or the terms of the mudaraba cooperation. As Shahibul Maal (owners of capital), mudharib, charity/ business from and contract. If it is ignored, ancertainly later will cause conflict and even legal problems. Nevertheless Ibn Taymiyyah stressed that most important from all forms of cooperation is to maintain and administer justice.

\section{Deliberation}

Before implementing pricing policies, advance the government should conduct consultations with the peoples concerned. When associated with today, especially when associated with Pancasila democracy, then a consultation 
should be carried out democratically. That is, in a deliberation everyone has the right to express his opinion. If those opinions may no longer find the word consensus, voting can be done. Thus, the discussion really overwhelmed value.

Clearly, he explained disadvantages and dangers of pricing arbitrary will not gain widespread support, such as the emergence of the black market or the manipulation of the quality level of goods sold at a set price level. These dangers can be reduced, or even eliminated, if prices are set through a process of deliberation and by creating a sense of moral responsibility and dedication to the public interest. ${ }^{21}$

Ibn Taymiyyah thinking about price regulation is also applicable to a variety of other factors of production. As in the labor market, deliberation is necessary to set the wages of labor. Deliberation goal in pricing is to protect employers and employees from exploiting mutual action between them. In the modern era, the deliberation is the right solution to tackle the exploitation that is often done by the owners of capital and labor providers. Because of the involvement of the government to set prices in a particular situation remains necessary.

\section{Prohibition of Riba}

Interest or usury practices in view of Ibn Taymiyyah refers to the prohibition of riba in the Quran. His view is not different from the views of Islamists among others. Riba is prohibited because of miserable people who require and obtain a number belonging to the wrong way.

Ibn Taymiyyah said two important functions of money are as a measuring tool and as a means of exchange, and he was opposed to trade money, because it means the transfer of functions of money from its real purpose. If money can be exchanged for money, it must be fully simultaneous exchange (taqâbud) and no delays.

In terms of inflation (reduction in value of the currency) coins, as happened in Egypt from the Mamluks, he asked Sultan examine the causes of the declining value of the money, and against currency debasement, and printing of the currency too much. Government authorities had to print currency coins (gold and silver) in accordance with the transaction value of the population, without any injustice therein. Ibn Taymiyyah said justice must be maintained among the population in relation to financial problems. A financial manager, did not have the right to distribute directly according to his own will.

Ibn Taymiyyah also prohibits the authorities use the gifts they have received for their rights beyond the individual interest. He also opposes

${ }^{21}$ Economic Development Center of Islamic studies and Islamic University of Indonesia in Yogyakarta, Ekonomi Islam (Ed. 4; Jakarta: Raja Grafindo Persada, 2014), p. 112. 
spending for poor institutions, such as prostitution, singer and comedian. Spending public finances should be given priority to a number of things that are very important to the general welfare. It needs to be underlined in the statement above Ibn Taymiyyah which categorizes work comedian as a bad thing. According to the authors it can be considered in terms of the intent and purpose of the job. If droll bersendagurau just mere propaganda without any mission in which the authors agree with the statement of Ibn Taymiyyah, but aims for preaching mission then according to the author it is legitimate for jokes these days be entertaining spectacle, especially for people who all day long with busyness. Prohibition of usury is intended to avoid the exploitation of one group against another in an economic activity that can lead to distortions in the economy.

Islam encourages a spirit of mutual cooperation and help each other among individuals so as to create a harmonious society built on the interaction between individuals who mutually support each other. The prohibition of riba is expressly disclosed Allah. in Q.S. Ali Imran/3:130.

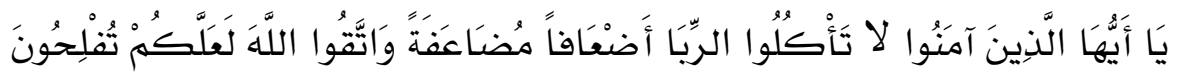

The meaning: "O ye who believe! Do not devour usury with a double, and fear Allah hopefully you got the victory"22

\section{Analysis of Moral in Economic Ibn Taymiyyah}

Islamic economics is a system implementation has Islamic ethics in economic activity that aims to develop moral/morals of society. Islamic economics not only provide legal justification for economic phenomenon occurs, but more emphasis on the importance of the moral spirit of Islam in any economic activity. Spirit is what should be the basis of development economics.

The value and honor of a person is determined by the moral and morals values. Moral in Islam is a strategic value in the existence of human life as a moral regarding the multidimensional aspects. Islam has set how human morality against his creator, the human character of the Apostle, the human character of the environment, and human morals against one another. All of it is set to be order of life orderly, organized, peaceful and prosperous. Islamic morality in the economic aspects concerning all the dimensions and economic activity in order to achieve harmony and continuity for the welfare of mankind.

${ }^{22}$ Ministry of Religion, op. cit., p. 66. 
Once the importance of Islamic morality that Prophet. He said: (إنها بعثت لأتهم مكارم الأخلاق). 'I was sent only to enhance noble character ". Because of economic activities concerning human behavior, then this is where it is located urgency moral character according to Ibn Taymiyyah became a cornerstone in running the economy. Without the moral values/morals in running the economy, the economy will experience chaos and uncertainty.

Grounding moral/morals in economic thinking Ibn Taymiyyah seen in economic principles are developed, as described previously. The principle of balance in the market mechanism according to Ibn Taymiyyah could be achieved if all the people involved in it are trustworthy, honest and not unjust. This is where he thinks it takes justice as the parent of a moral $/$ morals.

The principle of cooperation in economic activity also led to the foundation of moral/morals. In terms of cooperation Ibn Taymiyyah did not explain in detail, but he stressed that the essence of all forms of cooperation is to maintain and administer justice.

Then, in the use of property rights he says that every individual has the right to enjoy his property, use it productively, move and protect from superflouos, however, that right is limited by a number of conditions, which are not allowed to use for the purpose luxuries and in a way forbidden, such as fraud, forgery, and fraud in scale or size.

Ibn Taymiyyah also said that before implementing pricing policies, first the government must carry out consultations with the peoples concerned because pricing is arbitrarily by the government would pose a danger and loss to the community. Similarly, between workers and employers needed deliberation to determine the salary/ wages to avoid a gouge. Ibn Taymiyyah thought this is the right solution to address the salary payment system for civil servants and the payment of wages for workers in Indonesia. Especially lately where workers often hold demonstrations due to unilateral wage fixing of capital owners or employers and the government, without involving the workers so that workers or workers often feel exploited or harmed.

The prohibition of usury, according to Ibn Taymiyyah was intended to avoid the exploitation of one group against another in an economic activity that can lead to distortions in the economy.

The scholars agreed riba only apply to six types of treasures that exist in the hadiths of the Prophet, namely: gold, silver, dates, al-sya'ir (wheat), al-burr (red wheat) and salt. So there should not exchange gold for gold, silver for silver, wheat by wheat, dates with dates and salt with salt, but with the same weight and cash (cash) transactions in the assembly contract. In this case the schools of al-Zhahiriyah argue that usury is not applicable in addition to the six types of property and no illat that can be used as the basis for an analogy in others. Meanwhile majority Jurisprudence Expert equated with six kinds of 
treasure that all kinds of treasure that same function (ilaat her). But then, they disagree on the determination ilaat ribawi on the type of the property. Ibn Taymiyyah explains more about the gods of gold and silver (dinar and dirham) is as priceless this (al-tsamaniyah) is not on the scale as the opinion of the majority of the scholars.

Listening to the economic principles of Ibn Taymiyyah is known that everything boils down to fairness. Justice is the moral teachings/main character in Islam. Every country that wants security, peace, happiness and success for the people must hold the moral parent.

Islam commands to mankind to be fair in all aspects of life both for themselves, their family and to others even to the enemy reaching any. Justice in the Big Indonesian Dictionary defined: (1) is not one-sided; impartially; (2) favor the right; adhering to the truth; and (3) duly; not arbitrary. ${ }^{23}$

The term justice in Arabic comes from the word 'adl, which means equal and balanced. Fair in the same sense in this case means to divide as much or give the same rights to the people or groups with the same status. for example, employees who have the same group with a portion of the same tasks would receive the same salary. Fair in the sense of balance meant giving equal rights with obligations, or give it to someone according to his needs. Such as parents who are fair financeal needs according to his needs.

In the Qoran there are some verses that commanded people to be fair and justice both in general or specific nature. Of a general nature contained in Q.S. al-Nahl/16: 90.

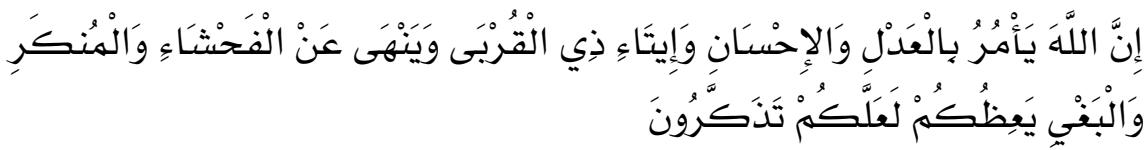

\section{The Meaning}

Actually Allah tells (you) to be fair and do good, gives aid to kin, and $\mathrm{He}$ forbids (commit) indecency, munkar, and hostility. He was a member of teaching you that ye may take heed. ${ }^{24}$

Justice special nature contained in Q.S. al-Nisa/4:58; Q.S. al-Hujurat/49:9; Q.S. al-Maidah/5:8.

Allah commands. to uphold justice in every aspect of life show that Islam wants a comprehensive justice both in the legal aspect, political, social, economic, and others. Became the talk of economic justice in a very

${ }^{23}$ Department of Education Culture, Kamus Besar Bahasa Indonesia (Jakarta: Balai Pustaka, 1990), p. 6

${ }^{24}$ Ministry of Religion RI, Quran and his Translates, p. 277. 
comprehensive and wide because he thinks economic justice is crucial in providing welfare for the people.

Islamic economics is part of Islamic moral manifestation in the economic field. The value and honor of a person is determined by the moral quality. Moral in Islam is very certain strategic value in human life Ahmadiyah Because moral concerns multidimensional aspect. Islamic morality in economics involves all the dimensions and the economic activity that is expected to achieve harmony, balance, and continuity of development for the welfare of mankind. Word of Allah. in Q.S. al-Bayyinah/98:7.

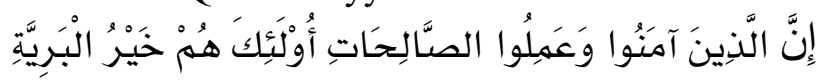

The meaning: "Verily, those who believe and do good deeds these are the best of men".

Ibn Taymiyah long for a society that is well equipped, organized on the basis of free enterprise, and personal property with the limits established by moral considerations and supervised by a fair provision that enforce sharia and work for the community.

\section{E. Conclusion}

1. The essence of economic principles developed by Ibn Taymiyyah rests on justice. because he thinks economic justice is crucial in providing welfare for the people.

2. In the moral aspect of Ibn Taymiyyah position as the economic foundation of Islam which inspired many economists Islam that arise in the future. Islamic morality in economics involves all the dimensions and the economic activity that is expected to achieve harmony, balance, and continuity of development for the welfare of mankind.

\section{REFERENCES}

Abdul 'Az m, Sa'id. 2005. Ibn Taimiyah, al-Tajd d al-Salaf wa al-Da'wah al-Iṣl hiyyah. Translates by Faisal Saleh and Khoirul Amru Harahap: Ibn Taimiyah, Pembaruan Salafi dan Dakwah Reformasi. Jakarta: Pustaka al-Kautsar.

Abdul Manan, Muhammad. 1998. Teori dan Praktek Ekonomi Islam. Yogyakarta: Dana Bhakti Wakaf.

al- Aṡqal n, Ibnu Hajar. 1947. Al-Durār al-Kāmilah fì A'yān al-Mi'ah alSaminah, Volume 1. D r al-Ma' rif.

Asmuni, Yusran. 1998. Pengantar Studi Pemikiran dan Gerakan Pembaruan dalam Islam. Jakarta: Raja Grafindo Persada. 
Azwar Karim, 2001. Ali Warman. Ekonomi Islam Suatu Kajian Kontemporer. Jakarta: Gema Insani Press.

Ibnu Rusl n, Muhammad Ibnu Sa' d. 2002. Haula Hayātuh Syaikh al-Islām Ibnu Taimiyah Rahimahullāh. Maktabah al-Manar.

Al-Zahab , Tazkirah al-Huffāz, Volume 4: Haidar Abad.

Yuliadi, Imamudin, 2007. Ekonomi Islam, Filosofi, Teori, dan Implementasi. Yogyakarta: Study and practice of Islamic Institutions: Muhammadiyah University.

Department of Education Culture. 1990. Kamus Besar Bahasa Indonesia. Jakarta: Balai Pustaka,

Economic Development Center of Islamic Studies and Islamic University of Indonesia in Yogyakarta, 2014. Ekonomi Islam . Jakarta: Raja Grafindo Persada.

Euis Amalia, Sejarah Pemikiran Ekonomi Islam. 2005. Jakarta : Pustaka Asatruss.

Hurșid, Ibr h m Zak. 1969. Da'irah al-Ma ârif al-Islāmiyah. Mațba'ah alSya'ab.

Ibnu Kaṡ r, 1966. Al-Bidāyah wa al-Nihāyah, Volume 13. Beirut Maktabah alMa' rif.

Ibnu Taimiyah, Minhāj al-Sunnah al-Nabawiyyah, Tahq q: Muhammad Rasyad S lim, Volume 2. Maktabah al-Riy ḍ al-Had sah.

Karnaen, and his friends in Adiwarman Azwar Karim, 2001. Pasar yang Sehat Menurut Ibnu Taimiyah. Jakarta: Rajawali Press.

Masyharuddin. 2007. Pemberontakan Tasawuf, Kritik Ibnu Taimiyah Atas Rancang Bangun Tasawuf. Kudus: JP Books.

Ministry of Religion RI, Alquran dan it's Translation. 2006. Jakarta: Pustaka Maghfirah..

Nur Chamid, 2010. Jejak Langkah Sejarah Pemikiran Ekonomi Islam. Yogyakarta: Pustaka Pelajar.

Sahilun A. Nasir, 1990. Tinjauan Akhlak. Surabaya: al-Ikhlas.

Sayyid Ahmad, Abd al-Fattah Muhammad. 2000. al-Tașawwuf baina alGhazalī wa Ibnu Taimiyah. Qairo: D r al-Waf,

Sunanto, Musyrifah. 2003. Sejarah Islam Klasik Perkembangan Ilmu Pengetahuan Islam. Bogor: Kencana.

Syauqi Bey in Hamzah Ya'qub. 1993. Etika Islam. Pembinaan Akhlaqul Karimah. Bandung: Dipenogoro,

Yuliadi, Imamuddin. 2007. Ekonomi Islam, Filososfi, Teori dan Implemtasi, Edisi Revisi. Yogyakarta: University of Muhammadiyah. 